International Journal of Instruction e-ISSN: 1308-1470 • www.e-iji.net

Article submission code: 20200922101505

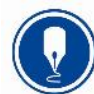

October $2021 \bullet$ Vol.14, No.4

p-ISSN: 1694-609X

pp. 627-642

Received: 22/09/2020

Revision: 10/04/2021
Accepted: 03/05/2021

OnlineFirst: 23/08/2021

\title{
The Effectiveness of E-Learning-Based Sociolinguistic Instruction on EFL University Students' Sociolinguistic Competence
}

\section{Mujiono}

Universitas PGRI Kanjuruhan Malang, Indonesia, moejie_nova@unikama.ac.id

\section{Siane Herawati}

Universitas PGRI Kanjuruhan Malang, Indonesia, siane.herawati@unikama.ac.id

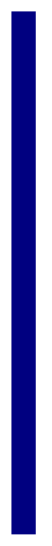

This study examined E-Learning-based sociolinguistic instruction's effectiveness of EFL university students' sociolinguistic competence. This study applied a quasiexperimental method with the Non-Equivalent Control Group Design. The participants of this study were 76 students purposefully recruited from a University in Malang, Indonesia. They were English Education majors and took the sociolinguistics course. The data were collected by a sociolinguistics test to measure the participants' sociolinguistic competence and analyzed using the independent sample t-test and Normalize Gain. The findings showed that the sociolinguistics competence from groups of students who had learned through elearning based on sociolinguistics instruction differs significantly from groups of students who had learned through face to face. The findings also showed that the experimental group was better in their post-test scores than the control group. The use of e-learning-based Sociolinguistic instruction contributed to developing EFL University Students' Sociolinguistic competence.

Keywords: e-learning, sociolinguistic instruction, sociolinguistic competence, EFL

\section{INTRODUCTION}

The development of Information Communication and Technology (ICT) utilizing computers and the internet has emerged as a new paradigm in education. This paradigm can be viewed from the increasing variety of learning methods and media used. ICT development impacts on the education system in higher education, starting from conventional learning systems to online learning ones. Today's technology has transformed learning more openly which can reduce the widespread use of traditional approaches (Man et al., 2019). The ICT development used as a learning medium uses a learning system through electronic learning known as e-learning (EL). EL is a learning medium utilizing a computer network or internet access (Kumar et al., 2018). EL system enables students to obtain various course materials and other academic activities via the internet. This case is because EL has characteristics such as fast access, flexible time,

Citation: Mujiono., \& Herawati, S. (2021). The effectiveness of e-learning-based sociolinguistic instruction on EFL university students' sociolinguistic competence. International Journal of Instruction, 14(4), 627-642. https://doi.org/10.29333/iji.2021.14436a 
economical, independent, beneficial for student learning, useable for active learning purposes, and learning outside the classroom (Ali et al., 2018; Salamat et al., 2018).

EL utilizing web-based learning is used today as another option instead of face-to-face. The results of the study Samir et al. (2014) reported that web usage is increasing. It makes educators put much effort into helping learners get interactive content full of multimedia. It has been shown to have a significant effect on the learning process. Teaching can be said to be successful to the extent to which learners can fully understand it. In this modern era, the teaching process has reached a new dimension. Teaching is not a one-sided affair. Teaching is a tripolar process in a modern development that teachers and subjects, and the environment will affect learners (Rkmvu-fdmse, 2015).

Previous research has shown that the need to use e-learning includes a lack of interest in students' homework assignments and participation in attending courses in the classroom (Benta et al., 2015). Other studies also revealed that e-learning could increase learners' involvement in attending lectures higher, offering them new skills by effectively managing their professional and personal lives. Moreover, on the contrary, those benefits are not available in traditional learning (Odhaib, 2018). The traditional teaching of 30 or 40 students is no longer effective (Walter \& Rangaswamy, 2014). The learners, particularly adult learners, need flexible new strategies to access flexible learning opportunities through globalization trends and the global economy (Ananga \& Biney, 2017).

EL technology can be an alternative solution in delivering courses in the global era. Therefore, EL technology has an impact on changes in the conventional learning process towards online learning. Hence, EL is important to be conducted. EL is an alternative to motivate students to speak (Rodrigues, 2015). Previous research results, such as (Mohammad et al., 2016), reported that EL effectively increases students' creativity compared to conventional lectures. EL can enhance students' motivation to learn independently (Samir et al., 2014; Mohammad Zare et al., 2016; Samir et al., 2014).

Instructional technology has generally become an integral part of everyday students to increase their interest in learning. The internet facilitates many possibilities for courses in technology integration in the classroom. EL is an internet-based learning tool that can be integrated into learning content-filled English subjects as a foreign language (EFL) class. One of the subjects is Sociolinguistic. Sociolinguistic is a scientific discipline with an object of study on the relationship between language and society (Ninsiana, 2018; Pathak, 2018; Iwuchukwu \& Iwuchukwu, 2018). Sociolinguistic also takes into account the conditions of the students. The presence of sociolinguistic in language learning, especially EFL, makes students understand how the classroom's speech community uses EFL.

Furthermore, various communicative learning methods were developed based on the sociolinguistic theory. The previous study reported that EFL students considered this course difficult because of the extensive reading load and conceptual, theoretical knowledge that EFL students must master (FX., 2015). EL can be used as an alternative 
learning resource, and at the same time, a learning medium with new technology that can meet the demands of EFL students in studying sociolinguistic courses in the digital era. This study examined the effectiveness of EL-based sociolinguistic instruction on EFL university students' sociolinguistic competence.

EL can be used as an alternative learning resource, and at the same time, a learning medium with new technology that can meet the demands of EFL students in studying sociolinguistic courses in the digital era. This research is intended to go further on the influence of EL-based sociolinguistic instruction on EFL university students' Sociolinguistic competence. It is expected from this study that EL-based sociolinguistic instruction can be identified as an effective strategy in developing sociolinguistic competence for University EFL learners.

\section{Literature Review}

The following literature review's key ideas include synchronous and asynchronous elearning, learning-based sociolinguistic instruction in EFL class, and sociolinguistic competence and EFL students.

\section{Synchronous and Asynchronous E-Learning}

E-learning can also be called virtual learning that applies asynchronous and synchronous learning models (Shahabadi \& Uplane, 2015a). In general, communication applications on the internet are divided into two types, namely, (1) synchronous system and (2) asynchronous system (Jethro et al., 2012; Zare et al., 2016). The synchronous system runs in real-time that whole students receive information to communicate directly with others together. An asynchronous system does not depend on time where all users can access the system and share between them according to their respective times. They can communicate using e-mail, online bulletin boards, newsgroups, and weblogs in different ways, not real-time (Jethro et al., 2012; Mohammad Zare et al., 2016). They explain that synchronous learning involves students and teachers interacting simultaneously in an online learning community without face to face with a predetermined time helped by an internet network (Shahabadi \& Uplane, 2015b). EL with an asynchronous model can be applied via teleconference or video conferences via a web network, where teachers and students can communicate simultaneously but in different places (Sana et al., 2018). Asynchronous learning is independent learning carried out independently, indirectly, or online with an online media intermediary. Asynchronous learning is interactive learning unlimited by time, place, or class constraints (Shahabadi \& Uplane, 2015b). In Asynchronous learning, students can interact with specific materials and with each other when they choose. Asynchronous EL is similar to synchronous EL, a student-centric process using online learning resources to facilitate sharing information that is not bound by time and place. Both are distance learning models that use online learning resources. Synchronous learning involves students and teachers interacting simultaneously in an online learning community without face-to-face with a predetermined time helped by an internet network. Asynchronous learning is interactive learning unlimited by time. 
Synchronous and asynchronous EL has a significant role in applying online learning by building social interaction among students and lecturers. EL makes students and teachers interact with each other, not limited by time and space (Goyal, 2012). With ICT development, EL has become a modern educational paradigm (Goyal, 2012). EL stimulates students to adopt technology tools in the classroom to be responsible for learning and evaluating their learning independently. A few previous studies showed that EL effectively developed students' critical thinking and higher-order thinking skills (Febro et al., 2016). They utilize EL improved analytical competence and learning (Gowda \& Suma, 2017; Liana, 2014). Therefore, the role of the teacher has shifted to facilitator supporting learning activities.

\section{E-Learning-Based Sociolinguistic Instruction in EFL Class}

By utilizing internet access and interactive media, online learning can be applied well (Ali et al., 2018). EL also integrates ICT applications related to teaching and learning (Wu et al., 2018). At this time, ICT learning in the college environment is very important due to the increasing information and communication for various purposes in line with science and technology development. The other findings of the study also showed that ICT application is one factor that can affect teaching and learning methods (Ben Youssef \& Dahmani, 2008). ICT allows students to reconstruct their knowledge. ICI changed its learning approach from Teacher-Centered Learning (TCL) to StudentCentered Learning) (Jaiswal \& Al-Hattami, 2020; Muianga et al., 2018). With this approach, students can obtain teaching materials independently through their personal computers in their respective places. Therefore, the level of independence of students and their communication skills will be better. Likewise, communication between students and lecturers occurs simultaneously or individually through computer networks with internet access. Thus, this particular learning method makes it easy for students to participate in flexible learning activities. ICT-based learning using EL has an impact on changing the learning culture. Students can independently learn these effects according to the appropriate approach to direct and organize themselves in learning. EL has implications for learner motivation in learning (El-seoud et al., 2009; Harandi, 2015). In implementing EL, at least the lecturers have competencies, such as mastering ICT in learning, using the internet as a learning resource to obtain teaching materials, and mastering learning materials by their field of expertise.

The delivery of courses in EFL classes in higher education, including EL-basedSociolinguistic courses, enables developing knowledge in the classroom where lecturers centrally provide lecture materials in a unidirectional manner, computer and network equipment. By accessing the internet, students can be active to learn. They can continue to communicate with each other anytime and anywhere by accessing the available online system. Such an approach will increase students' knowledge and help ease the lecturers to teach. Likewise, the process and teaching-learning data results can be stored in a database that is useable to repeat the process and produce even better lecture materials offerings. Web-based learning is increasingly needed for lecture programs that demand students' independent learning. As part of EL's development, the web is one of the 
internet technologies that have been developing for a long time and is the most commonly used in implementing education and distance training.

In short, EL-based Sociolinguistic instruction needs to be created as if students learn conventionally, but it is transferred to a digital system through the internet. In EL-based sociolinguistic instruction needs to adapt to the elements usually done in conventional learning systems. Such as starting from the formulation of operational and measurable goals, perceptions or pre-tests, arousing motivation, the communicative language used, materials descriptions, assignment, giving real examples, problem-solving, questioning, post-test, and following-up learning activities.

\section{Sociolinguistic Competence and EFL Students}

Learning the EFL is a holistic process requiring structural mastery and strategic rules. Students must also internalize sociolinguistic rules to help them choose the right form (Mede \& Dikilitaş, 2015). EFL learning materials are about grammar and, most importantly, concern the language-speaking community's usage and culture. Language and culture have integral interconnected relationships (Choudhury, 2013; Liton \& Madanat, 2013; Baydak et al., 2015). A language is a form of social-cultural interaction in the community. Interaction is intended more specifically, namely the interaction in EFL learning. The students' competence in speaking English, especially in good and correct English, will be realized if those competencies are supported by the language teachers' and the learners' sociolinguistic competence. This sociolinguistic mastery is important because it is a science studying the relationship between language and the speaking community, and it is also a science studying the purpose and function of language (Bayyurt, 2016). In EFL learning, sociolinguistic is used to explain how people speak differently in diverse social contexts. An educator who wants the EFL learning process to be successful, of course, needs to pay attention to the context of the conversation so that students can appropriately comprehend the materials presented. Sociolinguistic contribution to EFL teaching is indicated by the determination of language variations and registers; sets of language items related to social groups (Ronald \& Janet (2015) used in the learning process. Their sociolinguistic competencies determine EFL lecturers' ability to select language variations, such as standard, official, casual and familiar varieties. These competencies lead to using language variations typical to students according to their situation. The speaker should know when is the right time and to whom these variations and registers are appropriate.

According to their formality level, language variations make students understand what variations to use when talking to their lecturers. The sociolinguistic role in the next EFL learning is about differences in language use in the classroom and students' social environment. In EFL learning, the register, in this case, the lecturer's talk, is often used by him when teaching students in the class. As a register, lecturers talk is only used in learning situations, so that lecturers talk is different from students' daily language outside the classroom. Lecturer talk is an integral part of EFL teaching (Kiasi \& Hemmati, 2014). The EFL learning process cannot fully use one variation or just one register in all learning activities. As a foreign language, English is not a language used by students in their daily lives, both at home and in their communities. This situation 
makes lecturers have to use different variations and registers in their lecturer talk. It is conducted in EFL learning so that students can receive the lesson from lecturers quickly. Sometimes registers like code-switching; alternating between two distinct languages, and code-mixing; mixing two languages Ronald \& Janet (2015) are done by both lecturers and students when they do not find pronouns matching the English vocabulary. Hence, in speaking in the classroom, they also use other languages than English. The use of code-switching in the classroom is closely related to the students' low competence and learning context (Argella et al., 2019). Another language interference in English is also sometimes encountered in students' performance. The role of sociolinguistic here is to provide strategies so that students can continue to master English well.

Another role of sociolinguistic is its contribution to the development of various approaches and methods of language learning. This contribution was initiated by Hymes' concept of communicative competence (Abdulrahman \& Ayyash, 2019). This concept emphasizes competence to communicate. Based on this concept, a person's language competence is characterized by thorough knowledge of the intended language system, including its use in real-life communication (Ahmed \& Pawar, 2018). A few language learning methods are based on sociolinguistic and the concept of communicative competence. They are linguistic competence, competent sociolinguistic ability, discourse competence, and strategic competence (Klimova et al., 2019),

By analyzing the theories described above, it can be considered that sociolinguistic in language teaching can facilitate the success of the language learning process for EFL learners. The previous study supports that sociolinguistic in classroom instruction could contribute significantly to the development of foreign language teaching strategies (Bayyurt, 2016).

This research is intended to go further on the influence of EL-based Sociolinguistic instruction on EFL university students' Sociolinguistic competence. It is expected from this study that EL-based Sociolinguistic instruction can be identified as an effective strategy in developing Sociolinguistic competence for University EFL Learners. The following research questions are:

(1) Is there any difference between students who use EL-based Sociolinguistic instruction and those who were provided face to face on university students' sociolinguistic competence?

(2) Is the EL-based Sociolinguistic instruction effective in developing EFL university students' sociolinguistic competence?

\section{METHOD}

\section{Research Design}

This research applied a Quasi-Experimental with the Non-equivalent Pretest-Posttest Design. It provides independent variable manipulation with subjects assigned not randomly for the treatment group and does not provide full control (Ary et al., 2010; Christensen et al., 2015). The variables of this study included the independent and dependent variables. The independent variables are EL-based-sociolinguistic treated for 
the experimental group and face-to-face treated for the control group. In detail, the nonequivalent pretest-posttest design can be presented in Table 1.

Table 1

Pre-test and post-test control group design

\begin{tabular}{llll}
\hline Groups & Pre-test & Treatment & Posttest \\
\hline Experiment & $\mathrm{Y}_{1}$ & $\mathrm{X}_{1}$ & $\mathrm{Y}_{1}$ \\
\hline Control & $\mathrm{Y}_{2}$ & $\mathrm{X}_{2}$ & $\mathrm{Y}_{2}$ \\
\hline
\end{tabular}

Notes: $\mathrm{Y}_{1}$ : pre-test of experiment group; $\mathrm{Y}_{2}$ : pre-test of the control group; $\mathrm{X}_{1}$ : using e-learning; $\mathrm{X}_{2}$ : using face to face; $\mathrm{Y}_{1}$ : post-test of the experimental group; $\mathrm{Y}_{2}$ : post-test of the control group

This research population was the English Language Education Study Program's undergraduate students of Malang, Indonesia taking the Sociolinguistics subject. This study's sample involved 76 sixth year students majoring in the sociolinguistics subject of 2019/2020 academic year at the English Language Education Study Program, Malang, Indonesia. The number of students was derived from two sociolinguistics classes. They consisted of A and B classes. Forty (40) students were class A and 36 students of class B. The students were recruited purposively from two classes and then divided into the experimental group (40 students), which studied via e-learning, and the control (36 students) group studied by face-face. The selecting of those groups was based on some considerations: (1) sociolinguistic course in both class the same lecturer taught a dan B; (2) since this an educational setting study, the classes were not possible to be reorganized.

The sociolinguistic test was used to measure the sociolinguistic competence of the participants. This test consisted of five topics: code, language aspect, language attitude, social dialect, register, and varieties. The test was criterion-referenced, aiming to measure the sociolinguistic competence of EFL learners on the scoring rubric. It provided a measure of quality based on five criteria, including understanding what is known, understanding of what is being asked, the logic in the sequence of problemsolving steps, the correctness of the answers on a four-rating scale ranging from 4 meaning "excellent" to 1 meaning "enough." This test was used as a pre-test and posttest given before and after e-learning-based sociolinguistic instruction interventions. To ensure test content validity, the test, including scoring rubrics, was validated and evaluated by two experts. Experts were required to validate and assess the test by completing a checklist for experts to validate the sociolinguistic competency test. The trial results were examined and analyzed by two raters. The researcher determined the spoken test's reliability level using the Cohen Kappa agreement (Landis \& Koch, 1977). The reliability of the instrument is presented in Table 2. 
Table 2

The level of Cohen Kappa agreement

\begin{tabular}{lll}
\hline Value of Kappa & Level of Agreement & \% Reliable Data \\
\hline $0-.020$ & None & $0-4.00 \%$ \\
\hline $0.21-0.39$ & Minimal & $4.00-15.00 \%$ \\
\hline $0.40-.059$ & Weak & $15.00-35.00 \%$ \\
\hline $0.60-0.79$ & Moderate & $35.00-63.00 \%$ \\
\hline $0.80-0.90$ & Strong & $64.00-81.00 \%$ \\
\hline Above- 0.90 & Almost perfect & $82.00-100 \%$ \\
\hline
\end{tabular}

Table 3

Computation of Cohen Kappa

\begin{tabular}{|c|c|c|c|c|c|}
\hline & & Value & $\begin{array}{l}\text { Asymptotic } \\
\text { Standard Error }\end{array}$ & $\begin{array}{l}\text { Approximate } \\
\mathrm{T}^{\mathrm{b}}\end{array}$ & $\begin{array}{l}\text { Approximate } \\
\text { Significance }\end{array}$ \\
\hline $\begin{array}{l}\text { Interval by } \\
\text { Interval }\end{array}$ & $\begin{array}{l}\text { Pearson's } \\
\text { R }\end{array}$ & .840 & .058 & 9.556 & $.000^{c}$ \\
\hline $\begin{array}{l}\text { Ordinal } \\
\text { Ordinal }\end{array}$ & $\begin{array}{l}\text { Spearman } \\
\text { Correlation }\end{array}$ & .828 & .065 & 9.104 & $.000^{\mathrm{c}}$ \\
\hline $\begin{array}{ll}\text { Measures of } \\
\text { Agreement }\end{array}$ & Kappa & .721 & .097 & 6.214 & .000 \\
\hline
\end{tabular}

The Cohen Kappa coefficient is .721, which indicated a moderate level (Landis \& Koch, 1977). The approximate value of significance for the above data was less than .05 (.000 $<.05)$. It means that rater one and rater two had an agreement.

An independent sample t-test statistically analyzed the data collected through the test. The analysis requirements test was then performed, namely the Lilliefors test for normality and the Fisher test for data homogeneity (Shatskikh \& Melkumova, 2016). The null hypothesis testing $\left(\mathrm{H}_{0}\right)$ was carried out at a significance level of $5 \%$ or $\alpha=.05$. The independent sample t-test was employed to test the difference between the mean of the two groups. The data analyzed in this study resulted from an independent sample ttest of significant differences between the students using EL-based-Sociolinguistic instruction and those using face-to-face on EFL learners' sociolinguistic competence.

The gain test of Hake (1999) was conducted to determine EL-based-sociolinguistic instruction's effectiveness on EFL students ' sociolinguistic competence. This test can be done with the formula shown in Figure 1.

$$
g=\frac{\text { Postest-Pretest }}{\text { Max score-Pretest }}
$$

Figure 1

Gain index formulation

\section{FINDINGS}

\section{Analysis of pre-test data}

The following table presents the independent sample t-test of pre-test and post-test for the experimental group. 
Table 4

Independent sample t-test of pre-test and post-test for the experimental group

\begin{tabular}{lllllll}
\hline Groups & $\mathrm{N}$ & Mean & Std. Deviation & T & Df & Sig. \\
\hline Pre-test & 40 & 69.95 & 7.635 & 2.339 & .4 & .022 \\
\hline Post-test & 40 & 73.425 & 7.722 & & & \\
\hline
\end{tabular}

Table 4 presented that the level of the statistically significant difference between pre-test and post-test of the experimental group was considered less than (.05) by using the $t$ test. It showed statistically significant differences between the pre-test and post-test of the experimental group where the pre-test received a mean of (69.95), and the post-test received a mean of 73.425 . The following table 5 presented the Independent sample $t-$ test of experimental and control groups for post-test.

Table 5

Independent sample t-test of experimental and control groups for post-test

\begin{tabular}{lllllll}
\hline Groups & $\mathrm{N}$ & Mean & Std. Deviation & $\mathrm{T}$ & Df & Sig. \\
\hline Experiment & 40 & 73.425 & 7.722 & 3.137 & 74 & .002 \\
\hline Control & 36 & 67.222 & 9.496 & & & \\
\hline
\end{tabular}

The statistically significant difference between experiment and control groups was considered less than $(0.05)$ by applying the independent sample t-test. It indicated that there were statistically significant differences between the two groups. The group that used e-learning received a mean value of (73.425), and the control group received a mean value of (67.222). The data also revealed that the statistically significant difference between the two groups with the significance value was $.002<.05$. More specifically, the gain index in both experimental and control groups are presented in Table 6

\section{Analysis of Gain Index Data}

The gain index was obtained from the difference between the post-test and pre-test scores. It was used to determine EL-based sociolinguistic instruction's effectiveness in both experimental and control groups.

\begin{tabular}{l|l}
\hline$<\mathrm{g}\rangle$ & Categories \\
\hline$(<\mathrm{g}>)>0.7$ & High \\
\hline $0.7>(<\mathrm{g}>)>0.3$ & Medium \\
\hline$(<\mathrm{g}>)<0.3$ & Low \\
\hline
\end{tabular}

Figure 2

The categories of gain index

Three categories of gain Index can be identified as well as 'high $(<\mathrm{g}>)>0.7$ ', 'medium" $(0.7>(<\mathrm{g}>)>0.3)$ ', and 'low $((<\mathrm{g}>)<0.3)$ ' (Coletta, Philips, \& Steinert, 2007). The gain index in both experimental and control groups are presented in Table 9 
Table 6

$\underline{\text { Results of gain index test for both experimental and control groups }}$

\begin{tabular}{llllll}
\hline Groups & Post-test & Pre-test & Gain $(\mathrm{G})$ & $\langle\mathrm{g}\rangle$ & Criterion \\
\hline Experiment & 73.425 & 69.95 & 3.475 & 0.116 & Low \\
\hline Control & 67.222 & 65.750 & 1.472 & 0.043 & Low \\
\hline
\end{tabular}

Based on the data presented in table $9,\langle\mathrm{~g}\rangle$ value in the experimental group was .116 and .043 for the control group meaning that the effectiveness of EL-based sociolinguistic instruction in the experimental group was low. The normalized gain graph for the two groups can be seen in graph 1 .

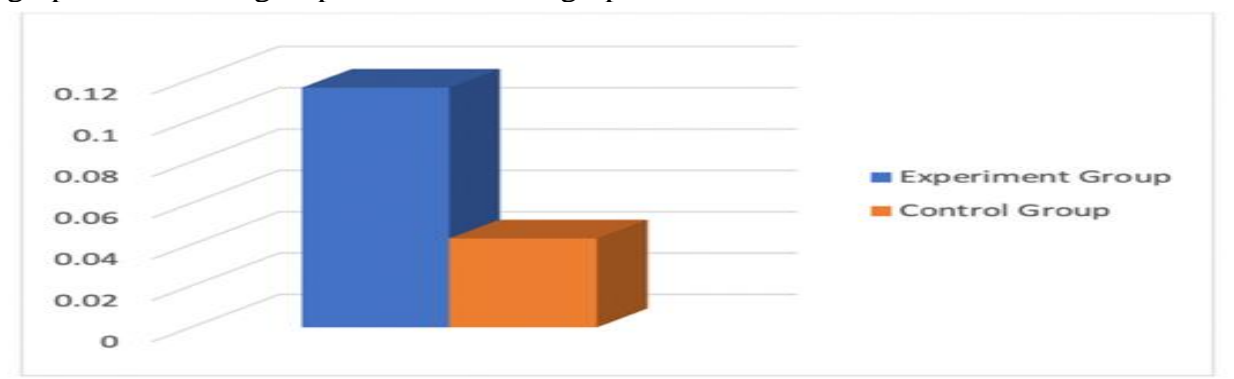

Graph 1

Normalized gain graph of Experiment and Control Groups

The above data clearly explained the comparison of the gain value between the experimental and the control groups. It could be justified that EL-based-sociolinguistic instruction effectively develops EFL university students' sociolinguistic competence.

\section{DISCUSSION}

Based on the collected data, this study has successfully revealed a difference in EFL learners' sociolinguistic competence between the students who were given EL and that delivered face-to-face. The findings also showed that EL was effective in increasing EFL learners' sociolinguistic competence. This result is supported by other studies reporting that EL is useful for students regardless of their backgrounds (Ali et al., 2018). EL is also an effective learning method in higher education (O'Hare \& Girvin, 2018). EL can improve learners' language competence, independent learning, and communicative competence (Soliman, 2014).

E-learning allows flexibility and providing the students the time to attend to other things such as working and so forth (Babu \& Srivedi, 2018). E-learning focuses more on learners' needs as an important factor in the educational process than on instructors or educational institutions (Arkorful \& Abaidoo, 2015). The use of e-learning can benefit instructors, educators, and students, particularly for students' performance enhancement in their learning process (Kew et al., 2018). It supports previous research reporting that e-learning takes advantage of highly effective teaching methods in universities to improve teaching and administration models (Arabasz, 2003). By utilizing e-learning, 
students have web access for college purposes and selected digital resources to support their studies, and they can join the discussion of the forums.

The use of e-learning in sociolinguistic instruction at universities can facilitate intercultural interaction between lecturers and learners. The previous studies indicated that intercultural online through EL could improve EFL students' competence in a social context, and online intercultural positively impacted sociolinguistic competence development and sociolinguistic awareness (Shu, 2019; Ritchie, 2011). Teaching sociolinguistic through EL allows lecturers and students to interact with each other. So, the Learners can share opinions related to lessons or the needs of learners' selfdevelopment. Teachers may put learning materials and tasks which learners do in a specific part on the web to be accessed by learners. The lecturers can also allow learners to access certain learning materials and exam questions that students can only access once and within a certain period. The process and the results of teaching and learning can be stored data in a database. It can be used to repeat teaching and learning as a reference to produce a better presentation of the subject matter. E-Learning effectively helps students save time, build their digital competencies, and lifelong learning for higher education (Nguyen et al., 2019). Saving time, students can study comfortably in their place. Students can choose to study relevant specific topics to their learning materials.

Delivering sociolinguistic materials through EL allows students and teachers to interact with each other easily, not limited by time and space (Goyal, 2012). Teaching materials using EL effectively develops students' critical thinking and higher-order thinking skills (Febro et al., 2020; Riggs et al., 2016). Furthermore, EL facilitates them to improve analytical competence and learning (Gowda \& Suma, 2017; Liana, 2014).

EL needs to be applied to create a successful learning environment and create meaningful and valuable learning activities (Mutambik, 2018). Sociolinguistic instruction based on e-learning creates a change in learning culture in the learning context. There are at least two essential components in building a sociolinguistic learning culture using the college's e-learning model. The two components include: (1) learners are required to be independent in learning with various appropriate approaches for students to direct, motivate, and organize themselves in learning. (2) lecturers can develop their knowledge and skills, facilitate learning, understand learning and the things needed in learning.

\section{CONCLUSION}

The results showed a significant difference between the EFL students using EL and that face-to-face on EFL learners' sociolinguistic competence. There was an increase in EFL university students' sociolinguistic competence. Normalize Gain indicated that EFL students with EL-based-Sociolinguistic instruction had higher sociolinguistic competence than students with face-to-face instruction. The use of e-learning contributed to developing students' sociolinguistic competence. Further research is needed to establish which factors maximizing sociolinguistic competence. 
This study's findings also provide recommendations for other researchers to further expand this study with different independent variables, i.e., prior knowledge of understanding sociolinguistic, linguistic competence, and communicative competence as factors that may predict sociolinguistic competencies for EFL university students.

\section{ACKNOWLEDGMENT}

The researchers would like to thank the Directorate of Research and Community Service (DRPM) from the Directorate General of Higher Education of Republic Indonesia for providing funding with this research through the scheme of "Penelitian Terapan Unggulan Perguruan Tinggi” (PTUPT) program.

\section{REFERENCES}

Abdulrahman, N. C., \& Ayyash, E. A. S. A.-. (2019). Linguistic Competence, Communicative Competence, and Interactional Competence. Journal of Advances in Linguistics, 10, 1600-1616. https://doi.org/10.24297/jal.v10i0.8530

Ahmed, S. T. S., \& Pawar, S. V. (2018). Communicative Competence in English as a Foreign Language: Its Meaning and the Pedagogical Considerations for Its Development. The Creative Launcher, II(Vi), 301-312.

Ali, M., Khaled Hossain, S. M., \& Ahmed, T. (2018). Effectiveness of E-Learning for University Students: Evidence from Bangladesh. https://doi.org/10.18488/journal.1007/2018.8.10/1007.10.352.360

Ananga, P., \& Biney, I. K. (2017). Comparing Face to Face and Online Teaching and Learning in higher Education. MIER Journal of Educational Studies, Trends \& Practices, 7(2), 165 - 179

Arabasz, P. (2003). Supporting E-Learning in Higher Education. October, 3(July), 1-4. Retrieved from http://net.educause.edu/ir/library/pdf/ERS0303/ecm0303.pdf

Argella, S., Ali, L., \& Krishnansamy, N. (2019). Code-Switching Phenomenon in English Language Classrooms at the Tertiary Level, 3(1), 35-42.

Arkorful, V., \& Abaidoo, N. (2015). The Role of E-learning, Advantages and Disadvantages of Its Adoption in Higher Education. International Journal of Instructional Technology and Distance Learning, 12(1), 29-42.

Ary, D., Lacobs, L. C., \& Sorensen, C. (2010). Introduction to Research in Education (Eight). United States of America: Wadsworth.

Babu, G. S., \& Srivedi, K. (2018). Importance of E-Learning in Higher Education : A Study. International of Research Culture Society, 2(5), 84-88.

Baydak, A. V., Scharioth, C., \& Il'yashenko, I. A. (2015). Interaction of Language and Culture in the Process of International Education. Procedia - Social and Behavioral Sciences, 215(June), 14-18. https://doi.org/10.1016/j.sbspro.2015.11.567

Bayyurt, Y. (2016). Current Perspectives on Sociolinguistics and English Language 
Education. The Journal of Language Learning and Teaching, 3(1), 69-78.

Ben Youssef, A., \& Dahmani, M. (2008). The Impact of ICT on Student Performance in Higher Education: Direct Effects, Indirect Effects, and Organisational Change. https://doi.org/10.7238/rusc.v5i1.321

Benta, D., Bologa, G., Dzitac, S., \& Dzitac, I. (2015). University Level Learning and Teaching Via E-Learning Platforms. Procedia Computer Science, 55(Itqm), 1366-1373. https://doi.org/10.1016/j.procs.2015.07.123

Choudhury, M. (2013). Teaching Culture in EFL: Implications, Challenges, and Strategies. https://doi.org/10.9790/0837-1312024

Christensen, L. B., Jhonson, R. B., \& Turner, A. L. (2015). Research Methods, Design, and Analysis (Global). Alabama: University of South Alabama.

Coletta, V. P., Philips, J. A., \& Steinert, J. J. (2007). Interpreting Force Concept Inventory Scores: Normalized Gain and SAT Scores. Physical Review Special Topics $\begin{array}{llll}\text { Physics } & \text { Education } & \text { Research, } & 3(1),\end{array}$ https://doi.org/10.1103/PhysRevSTPER.3.010106

El-seoud, M. S. A., Seddiek, N., El-khouly, M. M., \& Nosseir, A. (2009). E-Learning and Students 'Motivation: A Research Study on the Effect of E-Learning on Higher Education.

Febro, J. D., Catindig, M. A. C., \& Caparida, L. T. (2020). Development of E-Learning Module for ICT Skills of Marginalized Women and Girls for ICT4D. International Journal of Emerging Technologies in Learning, 15(16), 94-105. https://doi.org/10.3991/ijet.v15i16.14929

FX., Q. T. E. (2015). Menggunakan YouTube sebagai Sumber Belajar Sosiolinguistik Bahasa Inggris FX. Jurnal Penelitian, 1-10.

Gowda, R. S., \& Suma, V. (2017). A Comparative Analysis of Traditional Education System vs. E-Learning. IEEE International Conference on Innovative Mechanisms for Industry Applications, ICIMIA 2017 - Proceedings, (Icimia), 567-571. https://doi.org/10.1109/ICIMIA.2017.7975524

Goyal, S. (2012). E-Learning: Future of Education. Journal of Education and Learning (EduLearn), 6(4), 239. https://doi.org/10.11591/edulearn.v6i4.168

Hake, R. (1999). Analyzing Change/Gain Score. https://doi.org/10.24036/ekj.v1.i1.a10

Harandi, S. R. (2015). Effects of e-learning on Students' Motivation. Procedia - Social and Behavioral Sciences, 181, 423-430. https://doi.org/10.1016/j.sbspro.2015.04.905

Iwuchukwu, G. C. S., \& Iwuchukwu, R. N. (2018). Sociolinguistics and Language Education in Nigeria. Global Journal of Social Sciences Studies, 4(1), 13-22. https://doi.org/10.20448/807.4.1.13.22

Jaiswal, P., \& Al-Hattami, A. A. (2020). Enhancing Learners' Academic Performances 
Using Student-Centered Approaches. International Journal of Emerging Technologies in Learning, 15(16), 4-16. https://doi.org/10.3991/ijet.v15i16.14875

Jethro, O. O., Grace, A. M., \& Thomas, A. K. (2012). E-Learning and Its Effects on Teaching and Learning in a Global Age.

Kew, S. N., Petsangsri, S., Ratanaolarn, T., \& Tasir, Z. (2018). Examining the Motivation Level of Students in E-Learning in Higher Education Institutions in Thailand: A Case Study. Education and Information Technologies, 23(6), 2947-2967. https://doi.org/10.1007/s10639-018-9753-Z

Kiasi, M. A., \& Hemmati, F. (2014). The Importance of "Teacher Talk" in Teaching EFL Writing. Porta Linguarum, (22), 95-108.

Klimova, I. I., Klimova, G. V., \& Dubinka, S. A. (2019). Students' Communicative Competence in the Context of Intercultural Business Communication. XLinguae, 12(1), 207-218. https://doi.org/10.18355/XL.2019.12.01.16

Kumar Basak, S., Wotto, M., \& Bélanger, P. (2018). E-learning, M-learning, and Dlearning: Conceptual definition and comparative analysis. https://doi.org/10.1177/2042753018785180

Landis, J. R., \& Koch, G. G. (1977). Landis and Koch1977_Agreement of Categorical data. Biometrics, 33(1), 159-174.

Liana, T. (2014). Educational Paradigms in Contemporary Context and Educational Implications to the Potentiality Level of the Preadolescent Students. Educatia 21 Journal, (12), 20-28. Retrieved from http://educatia21.reviste.ubbcluj.ro/index_htm_files/Tausan_Liana.pdf

Liton, İh. A., \& Madanat, T. A. AL. (2013). Integration of Culture into ESL/EFL Classroom: A Pedagogical Perspective. 14(39).

Man, M., Azhan, M. H. N., \& Wan Hamzah, W. M. A. F. (2019). The conceptual Model for Profiling Student Behavior Experience in E-Learning. International Journal of Emerging Technologies in Learning, 14(21), 163-175. https://doi.org/10.3991/ijet.v14i21.10936

Mede, E., \& Dikilitaş, K. (2015). Teaching and Learning Sociolinguistic Competence: Teachers ' Critical Perceptions B. 2(3), 14-31. https://doi.org/10.17275/per.15.29.2.3

Muianga, X., Klomsri, T., Tedre, M., \& Mutimucuio, I. (2018). From Teacher Oriented to Student-Centered Learning, Developing an ICT Supported Learning Approach at the Eduardo Mondlane University, Mozambique.

Mutambik, I. (2018). The Role of E-learning in Studying English as a Foreign Language in Saudi Arabia: Students' and Teachers' Perspectives. English Language Teaching, 11(5), 74. https://doi.org/10.5539/elt.v11n5p74

Nguyen, Q. L. H. T. T., Nguyen, P. T., \& Huynh, V. D. B. (2019). Roles of E-Learning in Higher Education. Journal of Critical Reviews, 6(4), 7-13. 
https://doi.org/10.22159/jcr.06.04.02

Ninsiana, W. (2018). The Relationship between Language and Culture: a Sociolinguistic Perspective. Advances in Social Science, Education and Humanities Research, 280(Basa), 9-27. https://doi.org/10.4324/9780203695012-2

O'Hare, C., \& Girvin, B. (2018). A Narrative Overview of the Effectiveness of Elearning in Pharmacy Education. Journal of Pharmacy Practice and Pharmaceutical Sciences, 1(1), 01-09. https://doi.org/10.33513/ppps/1801-03

Odhaib, M. F. (2018). Does E-Learning Give a Better Result than Traditional Learning? Retrieved from International Journal of Computer Science and Mobile Computing website: www.ijcsmc.com

Pathak, V. (2018). Sociolinguistic Study of Advertisement Hoardings in Nagpur City. 6(4), 65-80.

Riggs, S. A., Linder, K. E., \& State, O. (2016). Actively Engaging Students in Asynchronous Online Classes. IDEA Center, Inc, (64), 1-10. Retrieved from https://eric.ed.gov/?id=ED573672\%0Ahttps://www.ideaedu.org/Portals/0/Uploads/Docu ments/IDEA Papers/IDEA Papers/PaperIDEA_64.pdf

Ritchie, M. (2011). Developing Sociolinguistic Competence through an Intercultural Online Exchange. Second Language Teaching and Learning with Technology: Views of Emergent Researchers, 123-141. https://doi.org/10.14705/rpnet.2011.000009

Rkmvu-fdmse, S. E. (2015). Need for Development of Teacher Readiness Skills in Imparting Value Education to Children Sampurna Guha Ramakrishna Mission Vivekananda University, Faculty of Disability. 6-7.

Rodrigues, P. D. (2015). The Impact of Online Learning in the Development of Speaking Skills.

Ronald, W., \& Janet, M. F. (2015). An Introduction to Sociolinguistics (Seventh). UK: John Wiley \& Sons, Inc.

Salamat, L., Ahmad, G., Bkht, Iftikhar, M., \& Saifi, Latif, I. (2018). Effect of ELearning on students' Academic Learning at University Level.

Samir, M., El-Seoud, A., Taj-Eddin, I. A. T. F., Seddiek, N., El-Khouly, M. M., \& Nosseir, A. (2014). E-Learning and Students' Motivation: A Research Study on the Effect of E-Learning on Higher Education. 9(4), 20-26. https://doi.org/10.3991/ijet.v9i4.3465

Sana, S., Adhikary, C., \& Chattopadhyay, K. N. (2018). Synchronous Vis-a-Vis Asynchronous Learning : A Blended Approach. (64431), 30-39.

Shahabadi, M. M., \& Uplane, M. (2015a). Synchronous and Asynchronous e-learning Styles and Academic Performance of e-learners. Procedia - Social and Behavioral Sciences, 176(February), 129-138. https://doi.org/10.1016/j.sbspro.2015.01.453 
Shahabadi, M. M., \& Uplane, M. (2015b). Synchronous and Asynchronous e-learning Styles and Academic Performance of e-learners. Procedia - Social and Behavioral Sciences, 176, 129-138. https://doi.org/10.1016/j.sbspro.2015.01.453

Shatskikh, S. Y., \& Melkumova, L. E. (2016). Normality Assumption in Statistical Data Analysis. CEUR Workshop Proceedings, 1638, 763-768. https://doi.org/10.18287/1613-0073-2016-1638-763-768

Shu, X. (2019). Sociolinguistics in Language Learning and Language Teaching. OALib, 06(11), 1-5. https://doi.org/10.4236/oalib.1105650

Soliman, N. A. (2014). Using E-Learning to Develop EFL Students' Language Skills and Activate Their Independent Learning. Creative Education, 05(10), 752-757. https://doi.org/10.4236/ce.2014.510088

Walter, T. M., \& A.Rangaswamy. (2014). Teaching Methods for Higher Education. Palayankottai: Government Siddha Medical College. 1-8.

Wu, C. H., Chen, Y. S., \& Chen, T. C. (2018). An Adaptive E-Learning System for Enhancing Learning Performance: Based on Dynamic Scaffolding Theory. https://doi.org/10.12973/ejmste/81061

Zare, M., Sarikhani, R., Salari, M., \& Mansouri, V. (2016). The Impact of E-learning on University Students' Academic Achievement and Creativity. Journal of Technical Education and Training, 8(1), 25-33. 